\title{
Alternaria dauci (palež lišća mrkve) i učinkovitost mjera kemijske zaštite nekim novijim fungicidima
}

\section{Sažetak}

Tijekom 2014. i 2015. godine izvršeno je ispitivanje djelotvornosti kemijske zaštite mrkve od napada patogena Alternaria dauci (Kuhn) Groves \& Skolko-uzročnika crnog sušenja te paleži lišća mrkve, u selu Stajkovci u okolici Grada Skoplja. Tijekom analize ispitana je učinkovitost zaštite od napada patogena Alternaria dauci (Kuhn) Groves \& Skolko novijim fungicidima u usporedbi s nekim starijim fungicidima, tretmanom u različitim uvjetima (oborine i vlage), odnosno u relativno vlažnoj 2014. godini i 2015., koja je bilježila manje oborina. Izvedenim pokusima utvrđeno je da je u 2014. godini, s mnogo oborina, najbolja djelotvornost postignuta primjenom fungicida Score 250 EC (difenakonazol) s indeksom učinkovitosti od 81,45\%. Nešto manji indeks učinkovitosti 79,99\%, te 79,53\% pokazali su fungicidi Sighnum (boskalid + piroksistrobin) i Quadris (azoksistrobin). Fungicidi Dithane M-45 (mankozeb) i Kocide (bakarni hidroksid) pokazali su indeks učinkovitosti 68,38\%,odnosno 70,91\%. Pri ispitivanjima u 2015. godini (manje oborina), najbolji indeks 93,62\% pokazao je fungicid Score 250 EC (difenokonazol). Dobru učinkovitost je pokazao i fungicid Quadris (azoiksistrobin) s indeksom učinkovitosti od 91,97\%. Nešto slabija učinkovitost je zabilježena kod fungicida Dithane M-45 (mankozeb) s indeksom učinkovitosti 75,85\%.

Ključne riječi: Alternaria dauci, mrkva, fungicidi, zaštita

\section{Uvod}

Uz povoljne klimatske i zemljišne uvjete za uspješan uzgoj mrkve, ta kultura se ne proizvodi u količinama koje bi zadovoljile potrebe za mrkvom u Republici Makedoniji te se najčešće uvozi iz susjednih zemalja koje imaju višak proizvodnje. U povijesnom razdoblju zabilježene su godine kada je domaća proizvodnja mrkve bila dostatna da se zadovolje potrebe u Republici Makedoniji, ali tada su trgovci, vezani trgovinskim ugovorima, uvozili mrkvu ili da smanje cijenu na domaćem tržištu ili bi jednostavno ispunili obveze ugovora. Ako se usporedi proizvodnja mrkve u Republici Makedoniji s brojem domaćinstava, kultura je zastupljena skoro u svakom domaćinstvu koje se bavi povrtlarskom proizvodnjom. Kod mnogih povrtlara mrkva se uzgaja na malim parcelama, za vlastite potrebe. Proizvodnja mrkve na velikim površinama za tržište, vrlo malo je zastupljena. Takvim vidom proizvodnje uglavnom se bave povrtlari koji žive u okolici velikih gradova. Na proizvodnju mrkve značajan utjecaj ima proizvodna cijena. Proizvodna cijena je uvjetovana troškovima proizvodnje koji su uzrokovani nizom svih potrebnih agrotehničkih tretmana kao i osiguranja proizvodnih uvjeta, kako klimatskih tako i tržišnih. Kod malih proizvođača u čijoj se proizvodnji koristi više čovjekov rad, a manje mehanizacije, proizvodni troškovi su veći.

Današnji globalni trendovi proizvođačima mrkve uvjetuju proizvodnju po konkurentnim cijenama, kako bi se izbjegli negativni utjecaji globalnih (agro)ekonomskih kretanja. Zbog negativnih posljedica tih trendova mnogi mali proizvođači će nestati, ako ne dostignu konkurentnu cijenu proizvodnje i ekonomske pokazatelje prodaje mrkve koji su prisutni na svjetskom nivou. Proizvođači se trebaju obrazovati da bi bili uspješniji, te smanjiti svaki nepotrebni trošak, naročito oko zaštite, izbjegavanjem nepotrebnih tretiranja, učinkovitim određivanjem potrebe tretiranja, jeftinijim i manje otrovnim sredstvima. Jedna od mogućnosti je i preorijentacija na 
organsku proizvodnju mrkve. Nužno je uklopiti se u ekonomski isplativiju proizvodnju mrkve ili se preorijentirati na drugu proizvodnu kulturu koja je isplativa. Mrkva kao kultura, najčešće postiže višu cijenu pri ranoj proizvodnji u odnosu na kasnu.

Proizvodnja mrkve ovisno o uvjetima proizvodnje u području - zemlji, može biti proljetna, pri čemu se sjeme sije od siječnja do ožujka, a berba je u lipnju i srpnju, a za uzgoj se koriste sorte ili hibridi kratke vegetacije. Sjetva jesenskih usjeva obavlja se od lipnja do kolovoza, a berba od listopada do prosinca. Zimska proizvodnja odvija se sjetvom od rujna do listopada i berbom od siječnja do travnja.

Značajni trošak pri proizvodnji je zaštita mrkve od uzročnika bolesti, korova, kukaca, nematoda, glodara i dr. Proizvodnja mrkve u Makedoniji je ugrožena napadom različitih patogena među kojima je i gljivica Alternaria dauci.

Ova gljivica je rasprostranjena na svim svjetskim područjima gdje se uzgaja mrkva i najvažniji je uzročnik bolesti mrkve u vlažnim uvjetima (Farrar i sur., 2004). Mnogi autori u svijetu navode velike štete od napada ovog parazita na mrkvi. Tako u Izraelu navode gubitke od 40-60\% (Ben-Noon i sur., 2003). U Ontariju u Kanadi A.dauci je jedna od glavnih patogena uzročnika bolesti na lišću mrkve (Saude i McDonald, 2014). Zaraze na mrkvi sa intenzitetom od 65 do $90 \%$ navode Soylu i sur. (2005), u uvjetima visoke vlage zraka i tla.

Proizvodnja mrkve u Republici Makedoniji vrši se na stotinu hektara varirajući manje-više od godine do godine, dok se u Republici Hrvatskoj proizvodnja mrkve odvija na nekoliko tisuća hektara, pa je time mrkva i zaštita od patogena A.dauci značajnija u Hrvatskoj.

Na svjetskom nivou mrkva je najčešće konzumirano povrće (Farrar i sur., 2004).

\section{Materijal i metode istraživanja}

Ispitujući djelotvornost različitih fungicida za zaštitu mrkve od napada $A$. dauci, izvršeni su pokusi 2014. i 2015. godine na mrkvi zasađenoj u plastenike za ranu proizvodnju u listopadu 2013. i listopadu 2014., u selu Stajkovci u okolici Grada Skoplja. Plastenici i najlon su uklonjeni u travnju, a mrkva je dalje uzgajana na otvorenom. Praćena je pojava patogena A. dauci na mrkvi uzgajanoj za ranu proizvodnju u plastenicima i na polju.

Ispitivani fungicidi su prikazani u Tablici 1. Ispitivanja su provedena na mrkvi kada su biljke bile otkrivene bez najlona u tri ponavljanja po 50 biljaka. Izvedena su po dva tretmana fungicidom. Prvi tretman izveden je 27.04.2014. godine, a drugi 14.05.2014. godine. U 2015. prvi tretman izveden je 04.05.2015., a drugi 17.05.2015. godine. Tretmani su rađeni leđnom prskalicom od 10 litara. Ocjena učinkovitosti ispitanih fungicida u zaštiti lišća izvršena je 10.06.2014. i 21.06.2015. godine. Dobiveni rezultati o zarazi lišća su obrađeni po formuli Townsend - Heubergera, a učinkovitost po Abbottu (Puntener, 1981).

Tablica 1. Primijenjeni fungicidi

Tabable 1. Rewiew of the examined fungicides in investigation

\begin{tabular}{clllc}
$\begin{array}{c}\text { Broj } \\
\text { Number }\end{array}$ & \multicolumn{1}{c}{$\begin{array}{c}\text { Pripravak } \\
\text { Fungicide }\end{array}$} & \multicolumn{1}{c}{$\begin{array}{c}\text { Aktivna tvar } \\
\text { Active ingradient }\end{array}$} & $\begin{array}{c}\text { Proizvođač } \\
\text { Producer } \\
\%\end{array}$ & $\begin{array}{c}\text { Koncentracija i doza } \\
\text { Conc. Doses } \%, \\
\mathrm{~kg} \mathrm{ili} \mathrm{ha}^{-1}\end{array}$ \\
\hline 1 & Dithane M-45 & 800 mankozeb & $\begin{array}{c}\text { Dow Agro } \\
\text { Science }\end{array}$ & $2,5 \mathrm{~kg} \mathrm{ha}^{-1}$ \\
\hline 2 & Kocide & Bakar hidroksid & Du Pont & $2,0 \mathrm{~kg} \mathrm{ha}^{-1}$ \\
\hline 3 & Quadris & 250 azoksistrobin & Syngenta & $1 \mathrm{~L} \mathrm{ha-1}$ \\
\hline 5 & Score $250 \mathrm{EC}$ & 250 difenokonazol & Syngenta & $0,5 \mathrm{~L} \mathrm{ha}^{-1}$ \\
\hline $\begin{array}{l}\text { Kontrola } \\
\text { Check }\end{array}$ & Signum & 867 boskalid + 87piroklostrobin & BASF & $0,75 \mathrm{~kg} \mathrm{ha}^{-1}$ \\
\hline
\end{tabular}




\section{Rezultati i rasprava}

Na mrkvi u Stajkovcima u okolici Skoplja utvrđen je napad patogena A. dauci. Makroskopski simptom napada bili su pojava pjega na starijem lišću i na lisnim peteljkama. Identifikaciju parazita vršili smo mikroskopskim metodama i Kochovim postulatima.

Simptomi napada patogena najčešće su se manifestirali na donjem starijem lišću, dok mlađe lišće u sredini rozete nije bilo zahvaćeno. Na oboljelom lišću napad je najprije bio na rubu lista pojavom lokalnih tamnih do crnih pjega nepravilnog oblika, obrubljenim žutim rubom ili žućenjem cijelog lista. Ovakve pjege su se javljale i na lisnoj peteljci, što se slaže sa navodima Dugdale i sur. (2000).

Gljivica se potom širila po lišću i lisnim peteljkama pri čemu se oblikovala forma micelije i konidije koje su obuhvaćale sve veći biljni dio. Povećanje pjega i širenje istih, vodilo je do spajanja i zahvaćanja sve većeg dijela listova i promjene boje u crnu ili crno smeđu te sušenja starijeg donjeg lišća (Slika 1). Kao posljedica napada ovog patogena u povoljnim uvjetima, lišće se brzo sušilo i izgledalo je kao spaljeno, što je utjecalo na smanjivanje i prinos korijena mrkve. Napad ove gljivice osobito je bio značajan u vlažnoj 2014. godini, posebno u nekim regijama i prilikom uzgoja mrkve na većim površinama gdje su nastajale štete, jer nije bila moguća strojna berba.

Također je značajna velika šteta zabilježena u slučajevima kad su biljke bile napadnute ovim parazitom u ranoj vegetaciji (kasne jesenje zaraze nisu imale značajan utjecaj na prinos i kvalitetu zadebljalog korijena mrkve). Uslijed napada gljivice A.dauci lišće je odumiralo i stroj pri vađenju korijena nije mogao uhvatiti lišće da bi pokupio zadebljani korijen mrkve. Korijenje se moralo vaditi ručno ili plugovima, pri čemu je proces berbe bio spor, a korijenje se oštećivalo što je poskupilo i ukupnu proizvodnju. Nastale su štete smanjivanjem prinosa korijena mrkve. Štete nastaju i pri sjemenskoj proizvodnji mrkve. U sušnim uvjetima ovaj je parazit na mrkvi bio manje značajan.

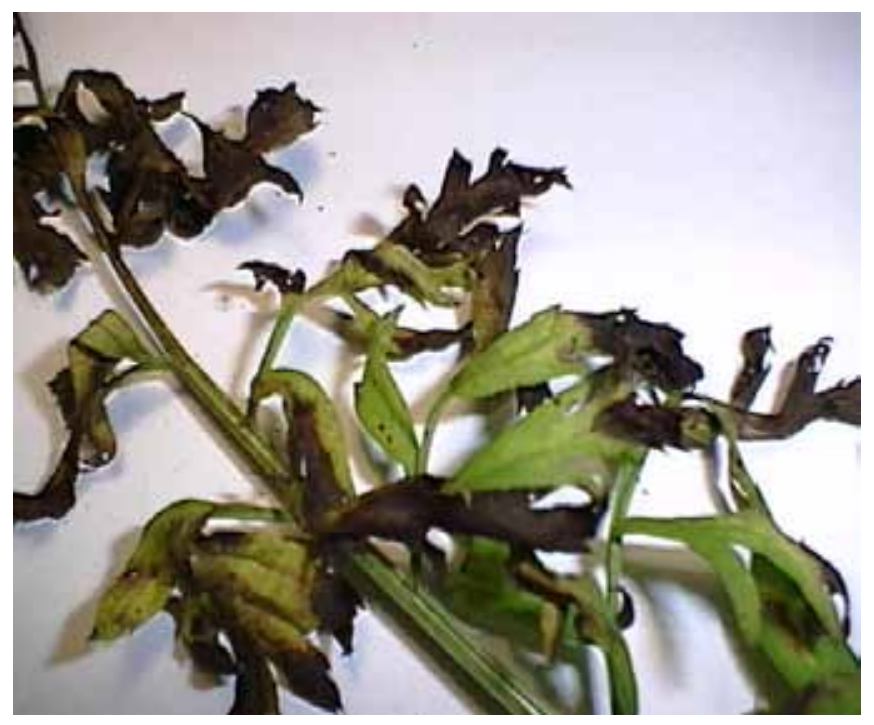

Slika 1. A. dauci na lišću mrkve

Figure 1. A. dauci symptoms on the leaves of carrot Izvor/Source: Autor/Author 
Za zaštitu mrkve od A.dauci vrše se i kemijski folijarni tretmani što je i predmet ispitivanja u ovom radu.

Učinkovitost primijenjenih fungicida u zaštiti mrkve od napada A.dauci je prikazana u Tablici 2.

Tablica 2. Djelotvornost primijenjenih fungicida u zaštiti mrkve od napada A. dauci

Table 2. The efficacy of tested fungicides in controlling $A$. dauci

\begin{tabular}{cccccc}
\hline \multirow{2}{*}{$\begin{array}{c}\text { Broj } \\
\text { Number }\end{array}$} & $\begin{array}{c}\text { Fungicid } \\
\text { Fungicide }\end{array}$ & \multicolumn{2}{c}{$\begin{array}{c}\text { Indeks zaraze lišća } \\
\text { Index of diseases } \%\end{array}$} & \multicolumn{2}{c}{ Učinkovitost } \\
Efficacy \%
\end{tabular}

Prema rezultatima prikazanim u Tablici 2 može se vidjeti da je u zaštiti mrkve od napada patogena $A$. dauci, najveći indeks učinkovitosti, 81,45\% u 2014. godini pokazao fungicid Score 250 EC (difenokonazol). Fungicid Sighnum (boskalid + piraklostrobin) pokazao je učinkovitost 79,99\%, a fungicid Quadris (azoksistrobin) 79,53\%. Nešto manji indeks učinkovitosti pokazao je fungicid Dithane M-45 (mankozeb) u iznosu 68,38\% te fungicid Kocide (bakarni hidroksid) sa 70,91\%. Pri ispitivanjima u 2015. godini najveći indeks učinkovitosti pokazao je fungicid Score 250 EC (difenokonazol) s indeksom učinkovitosti od 93,62\%. Visok indeks učinkovitosti 91,97\% je pokazao i fungicid Quadris (azoksistrobin). Nešto manji indeks učinkovitosti pokazao je fungicid Dithane M-45 (mankozeb) sa 75,85\%. Učinkovitost ispitivanih fungicida je bila manja u 2014. godini jer je ta godina imala mnogo oborina, dok je 2015. bila godina sa znatno manje oborina.

Za zaštitu mrkve od ove gljivice, kao i od nekih drugih gljivica, važne su preventivne mjere kao što su: agrotehničke, kemijske (dezinfekcija sjemena), genetske - otpornost sorti i hibrida prema A.dauci (Gugino i sur., 2006; Boeda Cora i sur., 2008; Karkleliene i sur., 2012). Bolji uspjeh u proizvodnji mrkve se postiže kada se provedu sve navedene mjere (Ben Noon i sur., 2003) i kemijske i preventivne. Prilikom korištenja kemijskih sredstava za tretiranje sjemena, važna je sjetva zdravog dezinficiranog sjemena. Sjeme je moguće dezinficirati kemijskim preparatima na primjerice, bazi iprodiona, tirama, 24-satnim potapanjem sjemena i sl. Prema navodima Nega i sur. (2003) dezinfekcija sjemena vrši se i tretmanom toplom vodom na $50^{\circ} \mathrm{C}$ u trajanju 10 minuta, pri čemu je učinkovitost od $85 \%$ do $98 \%$. Prema drugim autorima treba vršiti potapanje sjemena na $54^{\circ} \mathrm{C}$ u trajanju od 10 minuta. Potrebno je izbjegavati uzgoj mrkve na poljima visoke vlage i na niskim zabačenim mjestima. Pri vlažnim uvjetima (česte oborine i obilne rose), postoji mogućnost zaraze i širenja bolesti. Važno je izbjegavati duže vlaženje lišća i tla te navodnjavanje vršiti sustavom kap po kap. Do širenja gljivice dolazi kapima kiše pri kišovitom vremenu, pri zalijevanju orošavanjem, vjetrom, insektima, preko radnika i opreme koju se koristi. Na oboljelim biljkama i korjenju, konidije se mogu prenijeti transportom zrakoplovima, brodovima i sl. na velike razdaljine. Uzgojem mrkve na podignutim gredicama u rjeđem sklopu te većim razmakom redova, utječe se na smanjenje vlažnosti. Tlo na kojemu se vrši sjetva treba biti zdravo, oslobođeno biljnih ostataka iz prethodne proizvodnje i treba izbjegavati uzgoj mrkve u blizini prethodno zasađenih polja. Treba vršiti najmanje dvogodišnju rotaciju kultura- 
plodored, a u nekim slučajevima i četverogodišnju. Biljke treba redovito i pravilno obrađivati, prihranjivati i navodnjavati te da iste ne budu pod stresom ili oštećene. Učinkovitost kemijskih folijarnih tretiranja biljaka nekim fungicidima za zaštitu mrkve predstavljena je u ovom radu.

Pored fungicida i aktivnih tvari navedenih u pokusima za zaštitu mrkve od ovog patogena, koriste se i fungicidi na bazi aktivnih tvari: pirimethanil (Scala), mankozeb 750 (Dithane DG NeoTec), kombinacija dvaju aktivnih tvari: azoksistrobin + difenokonazol (Ortiva Top), triflosistrobin + tebukonazol (Nativo 75 WG) i dr. Fungicidi na bazi određenih aktivnih tvari u nekim zemljama se koriste, dok u drugima nemaju dozvolu. To su: klorthalonil, propineb, fluazinama, kao i kombinacije dvaju aktivnih tvari iprodion + karbendazim, trifloksistrobin + cimoksanil i dr. Fungicidi starijeg datuma su: Dithane M-45(mankozeb), Kocide (bakarni hidroksid), Antrakol (propineb) i neki drugi koji su se ranije koristili, a sad su zamijenjeni fungicidima novije generacije. Primjena fungicida za zaštitu mrkve od patogena A.dauci u Republici Makedoniji se rijetko provodi, jer je napad ovog parazita izražen u uvjetima visoke vlažnosti, povoljne topline i u proizvodnji mrkve na većim površinama, što u Makedoniji nije slučaj u pogledu vlažnosti i površina uzgoja.

Osim upotrebe fungicida za zaštitu mrkve od ove gljivice, u nekim zemljama upotrebljava se antagonistički mikroorganizam Bacilus subtilis, te giberilin. Prema navodima nekih autora, giberilin (hormon) ima dobru učinkovitost pri zaštiti mrkve od A.dauci, ali pri nanošenju viška giberilina može se pojaviti nakupljanje hranjivih tvari iz zadebljalog korijena u lišće, a time do manjih prinosa.

\section{Zaključak}

Izvedenim pokusima ispitana je djelotvornosti novijih fungicida u usporedbi sa starijim fungicidima u zaštiti mrkve od napada patogena Alternaria dauci (Kuhn) Groves \& Skolko uzročnika paleži lišća mrkve u 2014. i 2015. godini u selu Stajkovci u okolici Skoplja (Republika Makedonija). Utvrđena je dobra djelotvornost. Najviši indeks učinkovitosti u 2014. godini pokazao je fungicid Score 250 EC (difenokonazol) i isti je iznosio 81,45\%. Nešto manji indeks učinkovitosti od 79,99\% te 79,53\% pokazali su fungicidi Sighnum (boskalid + piraklostrobin) i Quadris (azoksistrobin). Najmanji indeks učinkovitosti u takvim vlažnim uvjetima pokazao je fungicid Dithane M-45 (mankozeb) i iznosio je 68,38\%. Izvedenim pokusima u 2015. godini utvrđeno je da je najbolji indeks učinkovitosti pokazao fungicid Score 250 EC (difenokonazol) s indeksom učinkovitosti od 93,62\%, kao i fungicid Quadris (azoksistrobin) s indeksom 91,97\%. Nešto manji indeks učinkovitosti 75,85\%, te 76,13\% pokazali su fungicidi Dithane M-45 (mankozeb) te Kocide (bakar hidroksid).

\section{Literatura}

Ben-Noon E., Shtienberg D., Shlevin E., Dinoor A. (2003): Joint action of disease control measures: a case study of alternaria leaf blight of carrot. Phytopatology, 3 (10), 1320-1328.

Been-Noon, E., Shtienberg, D., Shlevin, E., Vintal, H., Dinoor, A. (2004): Optimization of Chemical Suppression of Alternaria dauci, the Causal Agent of Alternaria Leaf Blight in Carrots. Plant Dis, 85 (11), 1149-1156.

Boedo C., Le Clere, V., Briart, M., Simoneau, P., Chevalier, M., Georgeault S., Poupard, P.(2008): Impact of carrot resistance on development of the Alternaria leaf blight pathogen (Alternaria dauci). European Journal of Plant Pathology, 121 (1), 55-66.

Dugdale,J.L., Martimer,M.A. ,Isaac,S., Collin, A.H. (2000): Disease response of carrot and carrot somaclones to Alternaria dauci. Plant Pathology, 49 (1) $57-67$.

Farrar, J., Pryor, B., Davis, M. (2004): Alternaria Disease of carrot. Plant Disease, 88 (8), 776-784.

Guigino, B.K., Carroll, J.E., Windmer, T.L., Chen, P., Abawi, G.S. (2006): Field evaluation of carrot cultivars for susceptibility to fungal leaf blight diseases in New York, Crop Protection, $26(5), 709-714$.

Karkleliene, R., Radzevičius, A., Dambrauskiene, E., Surviliene E., Bobinas, Č., Duchovskiene, L., Kavaliauskaite D., Bundiniene 0. (2012): Root yield, quality and disease resistance of organically grown carrot (Daucus sativus Röhl.) hybrids and cultivars. Žemdirbyste - Agriculture, 99 (4), 393 - 398.

Nega E., Ulrich R., Werner S., Marga, J. (2003): Hot water treatment of vegetable seed — an alternative seed treatment method to control seed-borne pathogens in organic farming. Journal of Plant Diseases and Protection, 100 (3), 220-234.

Püntener, W. (1981): Manual for field trials in plant protection. 2nd edition, Revised and enlarged. Basel, Switzerland:Ciba-Geigy, Ltd.

Soylu, S., Kurt, S., Soylu, M.E.,Tok,M.E (2005): First report of alternaria leaf blight caused by Alternaria dauci on carrot in Turkey. Plant Pathology, 54 (2): 252.

Saude C., Mcdonald R. M. (2014): Nitrogen and Fungicide Applications for the Management of Fungal Blights of Carrot. Hort.Science , 40 (5), 608-614. 


\section{Alternaria dauci and sucees of chemical measurements of protection with some newer fungicides}

\section{Abstract}

The control of the carrot Alternaria leaf blight diseases caused by Alternaria dauci (Kuhn.) Groves \& Skolko is actual problem. This paper shows results of the chemical control of Alternaria dauci (Alternaria leaf blight) on the carrot and there are presented results of application with some new fungicides.

The examination is done in 2014 and 2015 year in village Stajkovci near Skopje, Republic of Macedonia. The most efficacious fungicide applied in this research were Score 250 EC (difenoconazole) with 81,45\% of efficacy, Sighnum (boscalid + pyraclostrobin) - 79,99\%, Quadris (azoxystrobin) - 79,53\% of efficacy of protection with Alternaria dauci in 2014. Fungicide Score 250 EC (difenoconazole) efficacy was 93,62\% and Quadris (azoxystrobin) efficacy was 91,97\% in 2015 year. Fungicide Dithane M-45 (mancozeb) application index of efficacy in 2014 was 68,38\% and in 2015 it was 75,85\%. In 2014 fungicides Kocide (copper hydroxide) application index of efficacy was 70,91\%, and in 2015 index of efficacy was $76,13 \%$.

Key words: Alternaria dauci, carrot, fungicides, protection

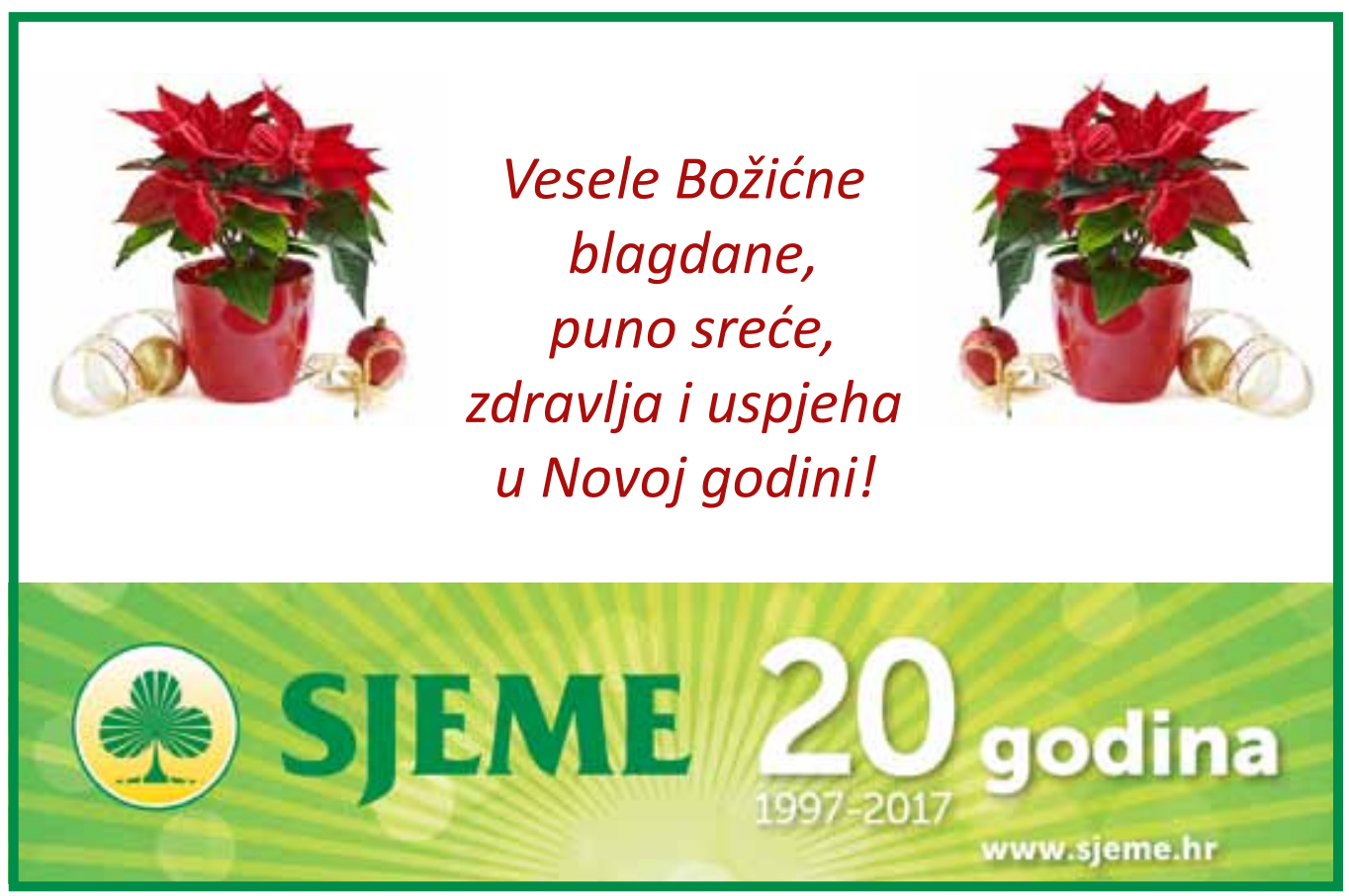

